\title{
Morphological Description of Extrinsic Muscles of the Thoracic Limb in a Specimen of Pudu (Pudu puda)
}

\author{
Descripción Morfológica de la Musculatura Extrínseca del \\ Miembro Torácico de un Espécimen de Pudú (Pudu puda)
}

Pamela Morales Muñoz; Catalina Arriagada Valdés; Jorge Sánchez Oñate \& Rodemil Medina Puentes

MORALES, M. P.; ARRIAGADA, V. C.; SÁNCHEZ, O. J. \& MEDINA, P. R. Morphological description of extrinsic muscles of the thoracic limb in a specimen of pudu (Pudu puda). Int,. J. Morphol., 39(2):366-370, 2021.

SUMMARY: The pudu (Pudu puda) is classified as an artiodactyl of the Cervidae family. It is a native species found in Argentina and Chile. It is estimated that its population has been substantially reduced due to several causes, such as loss of forests, predation, hunting, and vehicle accident. Therefore, this species is protected due to its vulnerable conservation status. The extrinsic muscles of the thoracic limb have great importance in the biomechanical functionality of the suspension of the limb, neck, and head, as well as participating in the movement of the thoracic wall and thoracic limb. The objective of the present study is to describe the extrinsic musculature of the thoracic limb of a specimen of pudu, comparing the results with those described for domestic ruminants in the classical anatomical bibliography. Basic procedures: All extrinsic muscles were analyzed, describing shape, distribution, origin, and insertion. The results indicate that the pudu specimen has anatomical characteristics similar to domestic ruminants; however, some differences should be considered. Main findings: The brachiocephalicus muscle has an evident clavicular intersection that separates it into cleidobrachialis, cervicalis, and mastoideus pars. The pectoralis superficialis muscle has two distinct and independent pars, and the pectoralis profundus muscle has a partial fusion with the latissimus dorsi and cutaneous trunci muscles. The subclavius muscle is small and has an elongated shape and goes deep into the cephalic vein, just at the point it is a tributary of the external jugular vein. The results of this study present specific anatomical features of $P u d u$ puda providing novel reference information and expanding scientific knowledge of this scarcely studied wild species.

KEY WORDS: Description; Extrinsic Muscles; Thoracic Limb; Pudu.

\section{INTRODUCTION}

The pudu is an artiodactyl of the Cervidae family. It is estimated that the current total population is less than 10,000 individuals. It is mainly threatened by territorial fragmentation, loss of forests causing their habitat to disappear, poaching, vehicle accidents, and predator attack, where the growing numbers of abandoned dogs that turn wild, represent an important cause of the decreasing numbers of these specimens (Weber \& González, 2003).

The pudu is an endemic species of Chile and Argentina. It has been in a vulnerable state since 1996 as indicated in the Regulation of Species Classification (Decreto 151, 2007), as it also belongs to the red list of the International Union for Conservation of Nature (IUCN) and is included in Appendix I of the Convention on International Trade in Endangered Species of Wild Fauna and Flora (CITES) (Weber \& González; Silva-Rodríguez et al., 2010).
The pudu has a low and robust body, with an approximate size of $90 \mathrm{~cm}$ long, $40 \mathrm{~cm}$ high and weighing 10 kilogram in its adult state. Males have two small, straight and sharp white antlers, which renew each year and vary in size between 6.3 and $9 \mathrm{~cm}$ in height (Bro-Jørgensen, 2008). The pudu is small in size and has a characteristic morphology that allows it to move easily and stealthily in the undergrowth (Eldridge et al., 1987).

Musculature is essential for the survival of every animal, especially in wild species that are predated as in the case of the pudu. Specifically, the extrinsic muscles of the thoracic limb are fundamental in the biomechanics of the limb suspension, supporting the tensile forces of the limb, neck, and head. In addition, due to the absence of the clavicle bone and because the articulation of the scapula with the thorax is classified as synsarcosis, the extrinsic 
muscles are responsible for linking the thoracic limb to the rest of the body (Sisson \& Grossman, 1982; Pellegrino et al.; 1998). Accordingly, the location of the center of gravity of the body shows that the thoracic limb supports more weight than the pelvic limb, both in season and during movement (Pellegrino et al.; König \& Liebich, 2005).

There is currently little scientific information on the anatomical characteristics of the pudu species (MoralesMuñoz et al., 2020). Therefore, it is necessary to generate novel scientific studies providing specific morphological knowledge of this species, thereby equally contributing in reducing its threat and vulnerability (Sánchez et al., 2017; Saldivia \& Villegas, 2019). Consequently, the objective of the present study is to describe the extrinsic muscles of the thoracic limb of a specimen of pudu (Pudu puda).

\section{MATERIAL AND METHOD}

We worked with a specimen of Pudu puda donated by the Servicio Agrícola y Ganadero (SAG) of the Ministry of Agriculture of Chile. The dissection was carried out in the Animal Anatomy Laboratory of Santo Tomás University of the School of Veterinary Medicine in Talca, Chile. The specimen corresponded to an adult female with size of $40 \mathrm{~cm}$ high and $63 \mathrm{~cm}$ long. The animal was euthanized due to the presentation of lumbar fracture in the lumbar region between L3-L4 possibly caused by outrage. The body was immediately fixed using a fixativepreservative solution. The solution was introduced by filling through the common carotid artery. Subsequently, the body was kept refrigerated during the entire descriptive process. Routine dissection instruments were used to dissect each muscle that forms the shoulder girdle, describing shape, origin and insertion.

\section{RESULTS AND DISCUSSION}

M. brachiocephalicus: It is divided in three portions, which correspond to the pars cleidobrachialis, pars cervicalis, and pars matoidea. These portions are described in domestic ruminants. The cleidobrachialis pars originates from the clavicular intersection until its insertion into the crest of the humerus bone. The clavicular intersection is observed as a cranial fibrous line to the scapulohumeral joint, which corresponds to the vestige of the clavicle bone, a similar situation to that described in other animals (Dyce et al., 2012). The pars cervicalis and pars mastoidea also originate from the clavicular intersection, then ascend until their insertion into the head, according to the direction their fibers take to reach the insertion site. This description is very similar to that described in domestic ruminants, although Sisson \& Grossman indicate that in domestic ruminants, the division between the pars cleidobrachialis, pars cervicalis, and pars mastoidea is unclear. In the case of the pudu specimen, the clavicular intersection is clearly evident and corresponds to the place of origin of all portions. In addition, the pars cervicalis has a wide fusion with the $\mathrm{m}$. omotransversarius, a situation not described in domestic ruminants; however, König \& Liebich, indicate that in the case of the horse, there is a muscular fusion of the pars mastoidea with the $\mathrm{m}$. omotransversarius (Figs. 1, 3A, 3B, 4 and 5).

M. pectoralis superficialis: The presence of two portions is clearly observed as described in domestic ruminants. These portions correspond to the descendens and transversus portions, which are very distinguishable and independent in the pudu specimen, contrary to what occurs in domestic ruminants, in which this muscle is poorly divided and differentiated (Sisson \& Grossman). Both portions originate from the sternum until they are inserted into the humerus bone. The transversus portion, despite being thin, is quite developed in contrast to that indicated by Sisson \& Grossman in cattle and small ruminants, in which it is thin and weakly developed (Fig. 5).

M. pectoralis profundus: It originates from the sternum and is then lateralized to insert into the greater tubercle of humerus (Figs. 1, 2A, 2B and 5). This muscle is larger than the $\mathrm{m}$. pectoralis superficialis and is partially fused with the $\mathrm{m}$. latissimus dorsi, with some muscle fibers also fused to $\mathrm{m}$. cutaneous trunci, a characteristic not described in the classical anatomical bibliography for domestic ruminants (Dyce et al.). Deep in this muscle, the axillary hollow associated with the brachial plexus is observed, as well as arteries and veins from the region.

M. subclavius: this muscle was not well-developed, similar to that described in other ruminants, except in the goat, in which it is described as very prominent (Sisson \& Grossman). It was also found to have an elongated shape unlike domestic ruminants, in which a trapezoidal shape is present (Sisson \& Grossman). The muscle goes deep into the cephalic vein, just at the point is a tributary of the external jugular vein (Fig. 5), information that is not described in the classical anatomical literature for domestic ruminants (Ashdown \& Done, 2011; Dyce et al.). Its muscle fibers are cranial and superficial to the $\mathrm{m}$. pectoralis superficialis and pectoralis profundus. It originates from the sternum to the scapular fascia, similar to that described in domestic ruminants (Figs. 4 and 5). 
M. Omotransversarius: This muscle is partially superficial to the m. infraspinatus (Morales-Muñoz et al.). It is highly fused to the m. brachiocephalicus (Fig. 3A), similar to the situation described in the horse (König \& Liebich); however,

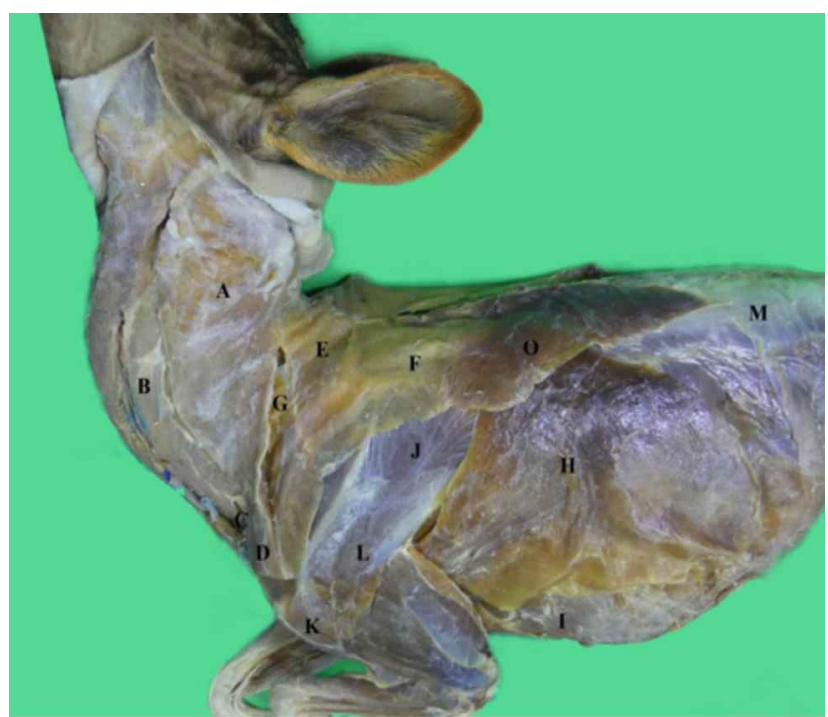

Fig. 1. Left side view of a pudu. $A=M$. Brachiocephalicus, pars cervicalis; $\mathrm{B}=\mathrm{M}$. Brachiocephalicus, pars mastoidea; $\mathrm{C}=\mathrm{M}$. Brachiocephalicus, intersection clavicularis; $\mathrm{D}=\mathrm{M}$. Brachiocephalicus, pars cleidobrachialis; E= M. Trapezius, pars cervicalis; $\mathrm{F}=\mathrm{M}$. Trapezius, pars thoracica; $\mathrm{G}=\mathrm{M}$. Omotransversarius; H: M. Latissimus dorsi; $\mathrm{I}=\mathrm{M}$. Pectoralis profundus; J= M. Infraspinatus; $\mathrm{K}=\mathrm{M}$. Deltoideus; pars acromialis; $\mathrm{L}=\mathrm{M}$. Deltoideus, pars scapularis, $\mathrm{M}=$ Thoracolumbar fascia.

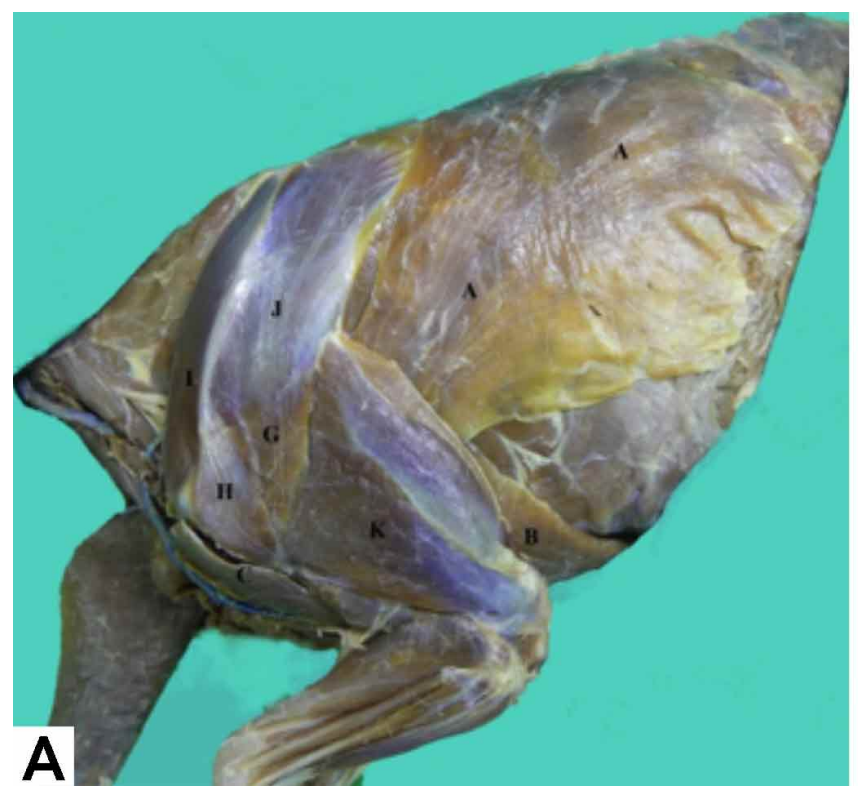

only partial fusion is described in domestic ruminants (Sisson \& Grossman). Due to the wide fusion that it presents with the $\mathrm{m}$. brachiocephalicus, it was only possible to observe the region of insertion at the level of the scapular spine and acromion. Its other insertion was observed in conjunction with the pars cervicalis of the $\mathrm{m}$. brachiocephalicus and not in the cervical region as indicated for domestic ruminants. Likewise, it was located toward the proximal an aponeurotic fusion with the $\mathrm{m}$. trapezius, a situation that also differs from that described for domestic ruminants (Figs. 1, 3A and 4).

M. trapezius: This muscle is superficial to the $\mathrm{m}$. rhomboideus, $\mathrm{m}$. supraspinatus, and $\mathrm{m}$. infraspinatus (Morales-Muñoz et al.). It has a pars cervicalis and a pars thoracica likewise described in ruminants and other domestic animals (Ashdown \& Done; Dyce et al.). It originates in the dorsal raphe of the neck and thorax, and its insertion is observed in the spine of the scapula, accordingly with the distribution described in domestic ruminants (Gloobe, 1989) (Figs. 1, 2A and 4).

M. rhomboideus: This muscle is observed deep in the m. brachiocephalicus and $\mathrm{m}$. trapezius and was well-developed in the studied specimen. As in other ruminant species, it has two portions, the pars cervicalis that is inserted into the spinal processes of the cervical vertebrae and the pars thoracica that is inserted into the spinous processes of the first thoracic vertebrae and the scapular cartilage (Gloobe; Popesko, 1998) (Figs. 2B and 3B).

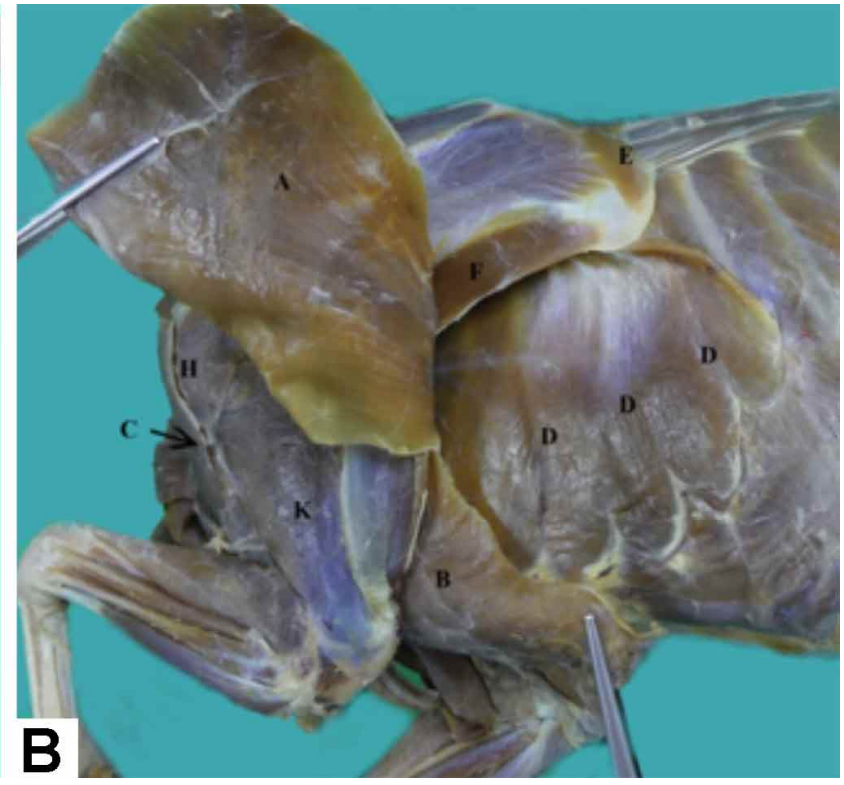

Fig. 2.A. 2B. Left side view of the scapular and brachial region of a pudu. M. Trapezius, m. Omotransversarius and m. Cutaneous trunci were removed. B. Have been sectioned and rejected $\mathrm{m}$. Brachiocephalicus and $\mathrm{m}$. Pectoralis profundus. $\mathrm{A}=\mathrm{M}$. Latissimus dorsi; $\mathrm{B}=\mathrm{M}$. Pectoralis profundus; $\mathrm{C}=\mathrm{M}$. Brachiocephalicus, pars cleidobrachialis; $\mathrm{D}=\mathrm{M}$. Serratus ventralis, pars thoracica; $\mathrm{E}=\mathrm{M}$. Rhomboideus; $\mathrm{F}=$ M. Teres major; $\mathrm{G}=\mathrm{M}$. Deltoideus, pars scapularis; $\mathrm{H}=$ Deltoideus, pars acromialis; $\mathrm{I}=\mathrm{M}$. Supraspinatus; J= M. Infraspinatus; K= M. Triceps brachii. 

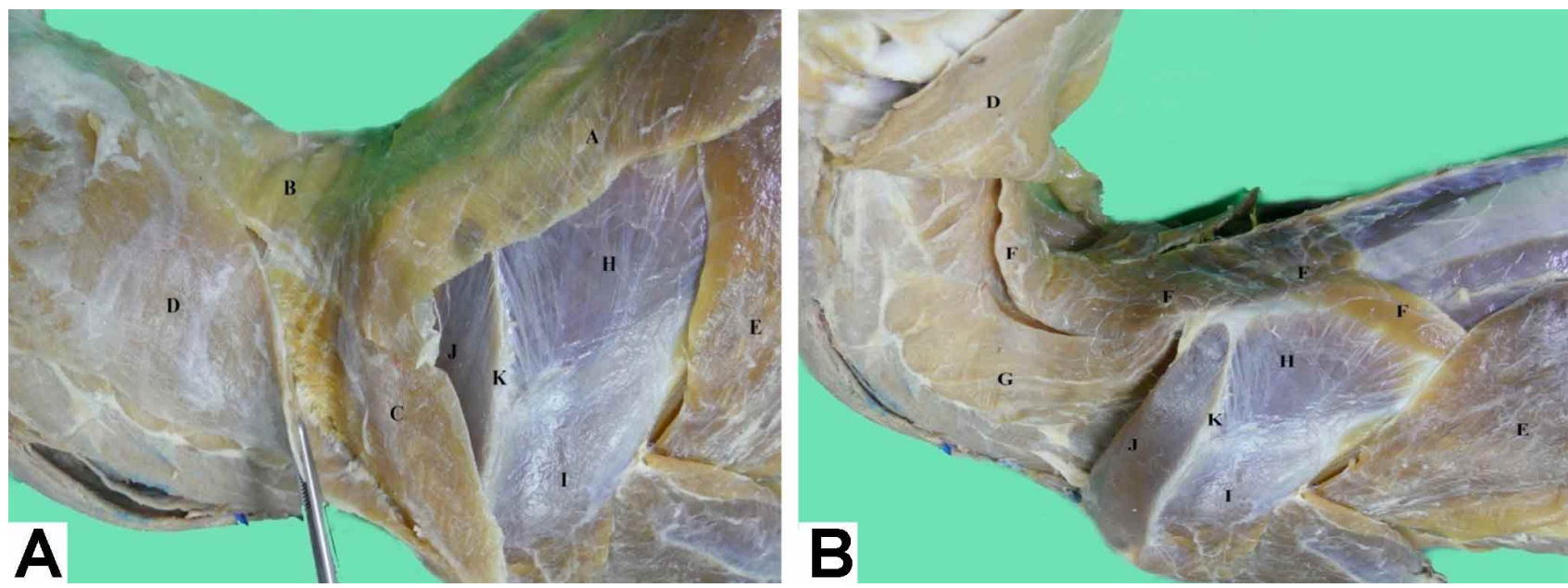

Fig. 3. A: Left side view of the cervical and scapular region of a pudu. B: The $\mathrm{m}$. Trapezius and m. Omotransversarius have been removed. $A=M$. Trapezius, pars thoracica, $B=M$. Trapezius, pars cervicalis; $C=M$. Omotransversarius; $D=M$. Brachiocephalicus, pars cervicalis (observe fusion of the muscles when taking with the gripper); $\mathrm{E}=\mathrm{M}$. Latissimus dorsi; $\mathrm{F}=\mathrm{M}$. Rhomboideus, pars cervicalis and pars thoracica, inserted in scapular cartilage; $\mathrm{G}=\mathrm{M}$. Serratus ventralis cervicis; $\mathrm{H}=\mathrm{M}$. Infraspinatus; I= M. Deltoideus, pars scapularis; $\mathrm{J}=\mathrm{M}$. Supraspinatus; $\mathrm{K}=$ Spine of the scapula bone.

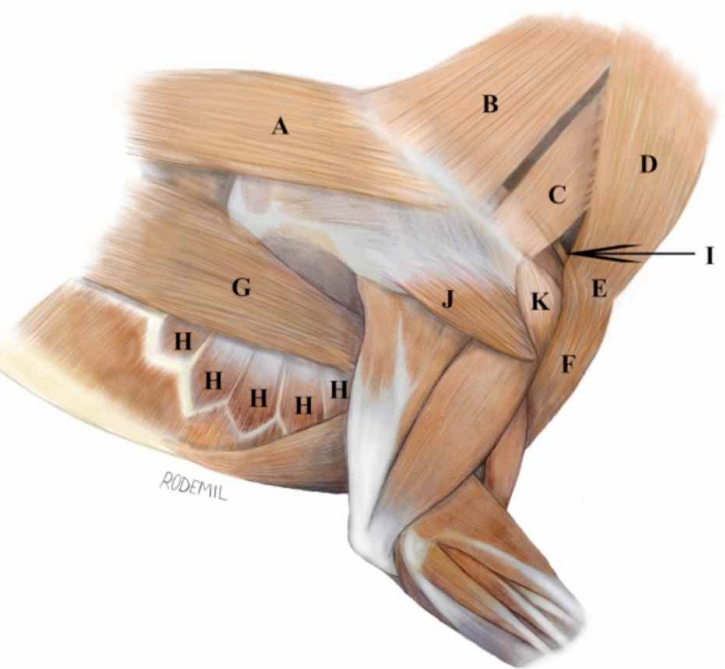

Fig. 4. 1llustration of the cervical, scapular, brachial, and thoracic regions of a pudu. Right side view. $\mathrm{A}=\mathrm{M}$. Trapezius, pars thoracica; $\mathrm{B}=\mathrm{M}$. Trapezius, pars cervicalis; $\mathrm{C}=\mathrm{M}$. Omotransversarius; $\mathrm{D}=$ M. Brachiocephalicus, pars cervicalis; $\mathrm{E}=\mathrm{M}$. Brachiocephalicus, intersection clavicular; $\mathrm{F}=\mathrm{M}$. Brachiocephalicus, pars cleidobrachialis; $\mathrm{G}=$ M. Latissimus dorsi; $\mathrm{H}=\mathrm{M}$. Serratus ventralis, pars thoracica; I= M. Subclavius; J= M. Deltoideus, pars scapularis; $\mathrm{K}=\mathrm{M}$. Deltoideus, pars acromialis.

M. latissimus dorsi: This muscle is observed deep in the m. cutaneus trunci. It has an asymmetrical and flattened shape and originates from the thoracolumbar fascia. Then, it is directed cranially and ventrally, reaching its insertion into the tuberosity of the teres major of the humerus bone. In general, it is very similar to that described in domestic ruminants (Popesko; Ashdown \& Done; Dyce et al.) (Figs. 1, 2A, 2B, 3A, 3B and 4). M.

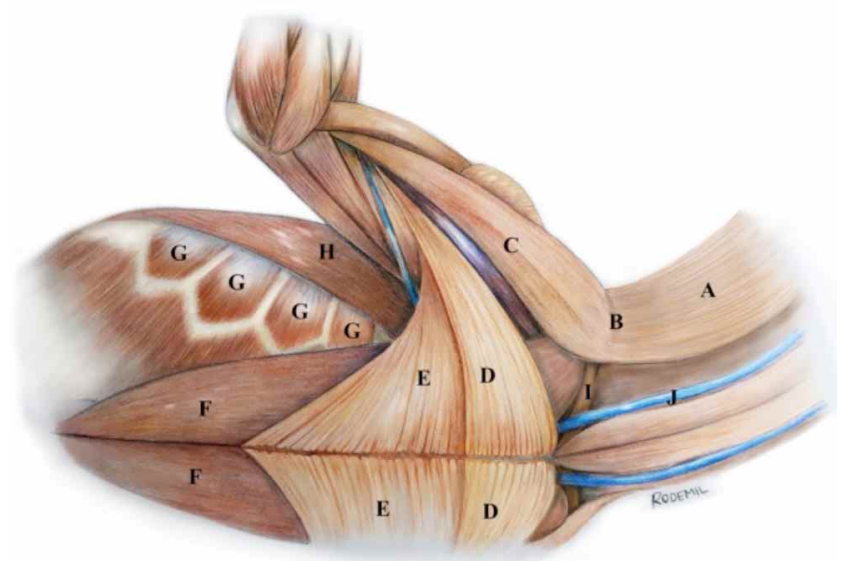

Fig. 5. Illustration of the cervical, scapular, brachial, and thoracic regions of a pudu. Right ventral view. $\mathrm{A}=\mathrm{M}$. Brachiocephalicus, pars cervicalis; $\mathrm{B}=\mathrm{M}$. Brachiocephalicus, intersectio clavicular; $\mathrm{C}=\mathrm{M}$. Brachiocephalicus, pars cleidobrachialis; $\mathrm{D}=\mathrm{M}$. Pectoralis superficialis, pars descendens; E: M. Pectoralis superficialies, pars transversus; $F=$ M. Pectoralis profundus; $\mathrm{G}=\mathrm{M}$. Serratus ventralis, pars thoracica; $\mathrm{H}=\mathrm{M}$. Latissimus dorsi; $\mathrm{I}=\mathrm{M}$. Subclavius; J= External jugular vein.

Serratus ventralis: This muscle is located medial to the scapula with a serrated shape. It is well-developed and is divided into a pars thoracica that originates from the second to the ninth rib and is inserted into the serrata face of the scapula. It is located deep in the M. latissimus dorsi. The pars cervicalis originates in the transverse processes of the third to the seventh cervical vertebrae and is widely inserted into the scapular cartilage until it reaches the serrata face of the scapula. It is less developed than the thoracic portion, thereby not differing from that described in the classical bibliography for domestic ruminants (Shively; Popesko) (Figs. 2B, 4 and 5). 


\section{CONCLUSIONS}

The descriptive study of the extrinsic muscles of the thoracic limb of a specimen of pudu (Pudu puda) allows us to conclude that the structures are similar to those described for domestic ruminants. However, some differences should be considered, both in the fusion of some muscles and in the development and shape of muscle structures. The great fusion between various extrinsic muscles joins the block work function and stability of thoracic limbs, as well as the neck and head. Consequently, the present data will be useful for veterinarians working in wildlife, zoos, and animal rehabilitation centers, providing novel reference data regarding the morphological features of $P u d u$ puda, thereby contributing to the knowledge of this scarcely studied vulnerable species.

MORALES, M. P.; ARRIAGADA, V. C.; SÁNCHEZ, O. J. \& MEDINA, P. R. Descripción morfológica de la musculatura extrínseca del miembro torácico de un espécimen de pudú ( $P u d u$ puda). Int. J. Morphol., 39(2):366-370, 2021.

RESUMEN: El pudu (Pudu puda) se clasifica como un artiodáctilo de la familia Cervidae. Es una especie nativa que se encuentra en Argentina y Chile y se estima que su población se ha reducido sustancialmente debido a varias causas, tal como la pérdida de bosques, depredación, caza y accidentes de vehículo. Debido a lo anterior esta especie está protegida por su estado de conservación vulnerable. Los músculos extrínsecos del miembro torácico tienen gran importancia en la funcionalidad biomecánica de la suspensión del miembro, el cuello y la cabeza, además de participar en el movimiento de la pared torácica y el miembro torácico. El objetivo del presente estudio es describir la musculatura extrínseca del miembro torácico de un ejemplar de pudu, comparando los resultados con los descritos para rumiantes domésticos en la bibliografía anatómica clásica. Se analizaron todos los músculos extrínsecos, describiendo la forma, distribución, origen e inserción. Los resultados indican que el espécimen de pudu tiene características anatómicas similares a las de los rumiantes domésticos; sin embargo, deben tenerse en cuenta algunas diferencias. Hallazgos principales: El músculo braquiocefálico tiene una intersección clavicular evidente que lo separa en pars cleidobraquial, cervical y mastoideo. El músculo pectoral superficial tiene dos porciones distintas e independientes, y el músculo pectoral profundo tiene una fusión parcial con los músculos latissimus dorsi y cutáneo del tronco. El músculo subclavio es pequeño y tiene una forma alargada y se ubica profundamente a la vena cefálica, justo en el punto en el que es un afluente de la vena yugular externa. Los resultados de este estudio presentan características anatómicas específicas de Pudu puda proporcionando información de referencia novedosa y ampliando el conocimiento científico de esta especie silvestre escasamente estudiada.

PALABRAS CLAVE: Descripción; Músculos extrínsecos; Miembro torácico; Pudu.

\section{REFERENCES}

Ashdown, R. R. \& Done, S. H. Atlas en Color de Anatomía Veterinaria. Rumiantes. 2nd ed. Madrid, Elsevier, 2011.

Bro-Jørgensen, J. Dense habitats selecting for small body size: a comparative study on bovids. Oikos, 117(5):729-37, 2008.

Decreto 151. Oficializa Primera Clasificación de Especies Silvestres Según su Estado de Conservación. Santiago de Chile, Ministerio Secretaria General de la Presidencia, BCN Legislación Chilena, Biblioteca del Congreso Nacional de Chile, 2007. Disponible en: http:// www.conaf.cl/cms/editorweb/transparencia/marco_normativo/DTO151_24-MAR-2007.pdf

Dyce, K. M.; Sack, W. O. \& Wensing, C. J. Anatomía Veterinaria. $4^{\text {th }}$ ed. Ciudad de México, El Manual Moderno, 2012.

Eldridge, W. D.; MacNamara, M. M. \& Pacheco, N. V. Activity Patterns and Habitat Utilization of Pudus (Pudu puda) in South-Central Chile. En: Wemmer, Ch. M. (Ed.) Biology and Management of the Cervidae. Washington D. C., Smithsonian Institution Press, 1987. pp. 352-70.

Gloobe, H. Anatomía Aplicada del Bovino. San José, Instituto Interamericano de Cooperación para la Agricultura (IICA), 1989.

König, H. \& Liebich, H. Anatomía de los Animales Domésticos. Tomo 1. 2nd ed. Madrid, Médica Panamericana, 2005.

Morales-Muñoz, P.; Arriagada-Valdés, C. \& Sánchez-Oñate, J. Morphological and morphometric description of thoracic limb intrinsic myology in a specimen of Pudu (Pudu puda). Int. J. Morphol., 38(1):915,2020 .

Pellegrino, F.; Tangelson, C.; Galliano, L.; Trevisan, L.; Sánchez, G. \& Puricelli, F. Homologation criterion between the scapular and pelvic waists and their associated structures. Rev. Chil. Anat., 16(1):75-82, 1998

Popesko, P. Atlas de Anatomía Topográfica de los Animales Domésticos. Tomo III. Pelvis y Miembros. $2^{\mathrm{a}}$ ed. Barcelona, Masson, 1998.

Saldivia, M. \& Villegas, F. Anatomical description of the bone segments that make up the skull of the Pudu puda Species. Int. J. Morphol., 37(1):167-73, 2019.

Sánchez, O. J.; Morales, M. P. \& Medina, P. R. Anatomical description of pelvic limb myology and its topographic relationship with vascular and nervous systems in Pudú (Pudu puda). Int. J. Morphol., 35(4):1370$6,2017$.

Silva-Rodríguez, E. A.; Verdugo, C.; Aleuy, O. A.; Sanderson, J. G.; Ortega-Solís, G. R.; Osorio-Zúñiga, F. \& González-Acuña, D. Evaluating mortality sources for the Vulnerable pudu Pudu puda in Chile: implications for the conservation of a threatened deer. Oryx, 44(1):97$103,2010$.

Sisson, S. \& Grossman, J. Anatomía de los Animales Domésticos. $5^{\mathrm{a}}$ ed. Barcelona, Masson, 1982.

Weber, M. \& González, S. Latin American deer diversity and conservation: A review of status and distribution. Écoscience, 10(4):443-54, 2003.

Corresponding author:

Pamela Morales Muñoz

Universidad Santo Tomás

Avda. Carlos Schorr 255

Talca - CHILE

E-mail: pmoralesm@santotomas.cl

Received: 22-09-2020

Accepted: 26-11-2020 